\title{
PLA2G4D wt Allele
}

National Cancer Institute

\section{Source}

National Cancer Institute. PLA2G4D wt Allele. NCI Thesaurus. Code C49373.

Human PLA2G4D wild-type allele is located in the vicinity of 15q15.1 and is approximately $28 \mathrm{~kb}$ in length. This allele, which encodes cytosolic phospholipase A2 delta protein, is involved in the hydrolysis of phospholipids. 